\title{
Competitive Pressure in Transition: A Role for Trade and Competition Policies?
}

\author{
Rosen Marinov \\ Graduate Institute of International Studies \\ marinov0@hei.unige.ch
}

\begin{abstract}
This paper investigates the effects of trade reforms and antitrust enforcement on the pricing behavior of firms, shedding light on the respective contributions of these policy instruments to the shaping of competitive markets. To this end, we use a rich panel data set of more than 25,000 manufacturing firms from Bulgaria, the Czech Republic, Estonia, Hungary, Poland, the Slovak Republic and Slovenia, spanning a five-year period. We find a positive and statistically significant relationship between domestic firms' mark-ups and industry protection, as reflected in MFN and trade-weighted import tariffs. The toughness of competition policy enforcement, captured by the number of final instance decisions delivered by national antitrust authorities and an index developed by the EBRD, has a negative impact of greater magnitude than import penetration. We also test for the significance of enacting major legislative amendments with regard to competition policy in the studied countries, as well as for differential effects in export-oriented and import-competing industries.
\end{abstract}

Keywords: Competition policy; Mark-up; Import penetration; Transitional economies JEL Codes: C23; K21; L4; P3

Acknowledgement: I would like to thank D. Neven, R. Baldwin and J. Konings for useful discussions and $\mathrm{H}$. Hall for helpful comments. Financial support under the EU/CEPR research and training network is gratefully acknowledged.

(C) The Author.

All rights reserved. No part of this paper may be reproduced without the permission of the author. 


\section{Introduction}

This paper investigates the role and interaction of trade and competition policies in the shaping of competitive markets. ${ }^{1}$ In contrast to ample theoretical analysis, empirical evidence on the effects of market intervention via either of the two mechanisms remains somewhat scarce in the literature. While turnarounds in trade policy have received some attention, cases of gradual transition have proven more difficult to investigate, mainly due to data availability constraints. Likewise, the inability to benchmark antitrust enforcement against a quantifiable common base has discouraged empirical analysis of this important policy instrument's impact. A growing number of firm-level studies confirm the premise that import competition might play a role in curtailing domestic market power. The effects of trade liberalization on companies' pricecost margins have been empirically explored by Levinsohn (1993), Harrison (1994), Krishna and Mitra (1998), and Bottasso and Sembenelli (2001). Focusing on instances of increased protection, Konings and Vandenbussche (2005) use a similar approach to investigate the impact of antidumping measures. These papers' findings are in line with theoretical predictions on the coercive effect of enhanced international competition. However, even in a small open economy the influence of import penetration could vary considerably across industries and, in some cases, may prove insufficient to discipline the pricing behavior of domestic firms. For lack of suitable explanatory variables, attempts to estimate the effects of national competition policy on company price-cost margins have remained much more limited. To date, the only firm-level investigation of this kind has been conducted by Konings et al. (2001). In a related analysis based on aggregate data, Hoekman and Kee (2003) use a large cross-country sample to test for structural breaks in estimated industry mark-ups, following the adoption of competition legislation.

A common feature of the studies to date is their dependence on a one-time switch of regime to identify the respective effects on market contestability. Moreover, the available enterpriselevel evidence is typically limited to the national borders of a single country. In light of the difficulties with quantifying trade and antitrust regimes, the robustness of the studied relationships should ideally be tested using alternative measures and specifications, as well as in consistent cross-country replications. The contribution of this paper to the existing body of literature is twofold. We trace the evolution of trade policy using detailed annual data and document the effects of tariff protection in seven Central and Eastern European countries.

\footnotetext{
${ }^{1}$ The terms competition policy and antitrust are used interchangeably throughout the paper. The underlying notion encompasses the correction of anticompetitive practices by undertakings and relevant authorities, as well as policy advocacy initiatives. Indeed, measures fostering the development of competitive culture and the natural selection among efficient firms are particularly relevant in the context of transition.
} 
In addition, we contribute to the hitherto limited evidence on the role of competition policy implementation, on the basis of transition economies' informative experience.

Former centrally planned economies offer an opportune setting for a study of trade and competition policies' interaction in influencing the emergence of competitive pressure. Notably, countries acceding to the EU set a particularly interesting precedent, in light of the shared blueprint for legislative and institutional reforms. The common legacy of extensively integrated production, both vertically and horizontally, ensured a broadly equivalent starting point for the economic transformation of post-socialist Central and Eastern Europe. While opening up to international trade and investment in the aftermath of the Council for Mutual Economic Assistance (Comecon/CMEA) introduced some contestability in product markets, imports alone could not foster the formation of strong competitive pressure in all industry sectors. Accordingly, properly designed and enforced antitrust rules had a crucial role to play in narrowing the considerable scope for market power abuses in the course of economic transformation. The interplay of trade and competition policies is also pertinent in light of the latter's relative decentralization in the process of European integration. Upon accession to the EU, member states adhere to a uniform trade regime, but retain a degree of autonomy in the formulation of antitrust rules. While the prospect of overlapping jurisdictions may have a strong disciplining effect, both on firms and national competition authorities, the possibility of sequential enforcement could undermine effectiveness. In that respect, further parallels can be drawn among transition countries at the outset of institutional reforms. Newly established antitrust agencies typically lacked the expertise to carry out sophisticated context-specific analyses, necessary for effective application of competition rules. Moreover, in the absence of prior experience with antitrust cases, post-socialist judicial systems were poorly equipped to handle appeals. In fact, the case law of the European Court of Justice has served as a natural reference point in this context, particularly at the more advanced stage of preparations for EU membership. Notwithstanding the shared commitment to legal and institutional alignment with the acquis communautaire, the studied economies' reform experiences are not fully symmetrical. The evolution of national regulatory frameworks exhibits considerable variation in timing and policy-making choices, which provide valuable insights regarding the emergence of competitive pressure. In our attempt to link outcomes to policies, we draw on cross-country, inter-industry and firm heterogeneity to disentangle the effects of changes in national trade and antitrust regimes from the overall impact of structural reforms across the future EU member states. 


\section{Evolution of Trade and Competition Policies}

\section{Trade Policy Realignment}

Economic transition from plan to market would be impracticable without investment liberalization and a broadening of import and export opportunities. Accordingly, as part of initial reforms, Central and Eastern European countries sought improved access to markets outside the former Council for Mutual Economic Assistance, opening up to greater import penetration in the process. Most transition economies covered in this study embarked on trade reorientation with the conclusion of bilateral Agreements of Association with the EU, commonly known as Europe Agreements. These initiatives also paved the way for legal and institutional harmonization along the lines of the acquis communautaire. Notably, the Europe Agreements contained provisions for the fundamental alignment of regulatory frameworks in the areas of competition policy and state aid to industries. Another common feature of the association treaties was the asymmetrical timetable, which governed the gradual liberalization of trade in goods - a maximum period of five years for the EU and ten years for the respective transition economies. Nevertheless, the EU maintained substantial levels of protection for a number of sensitive industrial products, such as certain textiles, some coal and steel products. Accession countries also applied some discretion in their specific liberalization commitments, in line with national priorities. The momentous Europe Agreements were accompanied by a number of bilateral and plurilateral arrangements redefining preferential trade relations in the region. Typically, the concluded free trade agreements included provisions for cooperation in the prevention of restrictive business practices that affect cross-border commerce, modeled on the relevant clauses of the Europe Agreements. In parallel, as a direct consequence of WTO membership, all studied countries undertook additional liberalization commitments on the principle of non-discrimination, guaranteeing Most-Favored-Nation (MFN) and national treatment. As a result, a gradual reduction of MFN tariffs was accompanied by stepwise introduction of preferential rates that covered a substantial share of the transition economies' trade. While, on aggregate, liberalized bilateral exchanges with the EU had by far the most significant economic impact, import competition among the other preferential trading partners was also increased.

Figure 1 presents an overview of the applied customs duties averaged over all manufacturing industries. An illustrative breakdown by two-digit NACE sectors and a chronological list of the relevant trade initiatives are provided in the appendix. Protection from import competition has generally been reduced over the examined period, albeit with uneven treatment of trading partners due to the expanding network of preferential agreements in the region. Moreover, the average figures conceal the considerable inter-sectoral heterogeneity in market access liberal- 
Figure 1: Average Applied Tariffs on Industrial Products

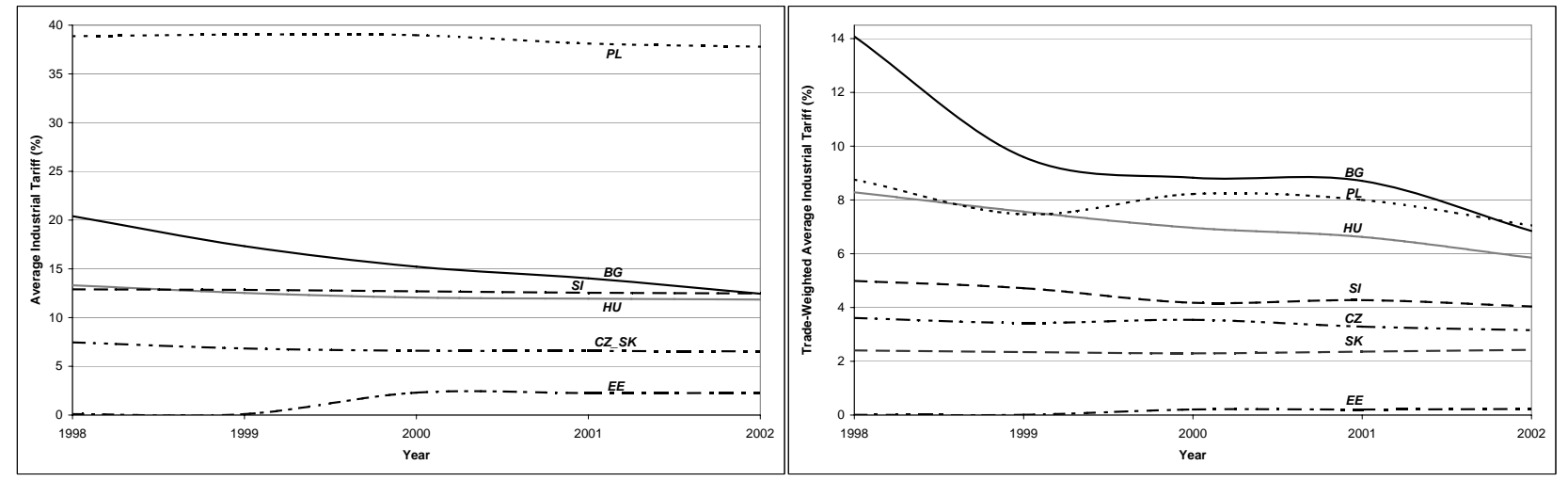

Source: WITS Database

ization within a single country. Import duties on different products falling within the same four-digit NACE sector have been modified at varying increments over the studied period. As a result, the average rates of protection corresponding to more finely delineated manufacturing industries exhibit highly asymmetrical patterns of transformation. For instance, as shown in figure 2, the increased tariff protection observed in Estonia after 1999 is concentrated solely in the food processing industry and varies significantly in magnitude across sub-sectors. By and large, even if the studied countries follow a broadly similar pattern in regional trade liberalization, significant differences inevitably emerge within and across narrowly defined industries. These considerations highlight the importance of accounting for barriers to import competition at high level of sectoral disaggregation and reflecting the specific clauses of relevant preferential trade agreements. However, although the MFN rates do not capture the latter, they may constitute a more exogenous measure of protection. Being an outcome variable, the trade-weighted tariff is susceptible to a certain bias, as the volume of imports under free trade agreements is not independent from the respective preferences granted. Moreover commercial flows are likely to be endogenous to productivity or endowment shocks.

\section{Competition Policy Implementation}

While the transition process entailed a wide array of structural reforms, the realm of competition policy had to be built from scratch in all Central and Eastern European countries, as a natural consequence of the common legacy of central planning. Accordingly, the gradual dismantling of trade barriers was accompanied by the introduction of legislation and institutions for the protection of competition. By 1993, all transition economies under review were regulated by recently adopted antitrust laws, which constituted a first approximation of the rel- 
evant EU rules. Notwithstanding some cross-country heterogeneity in the timing of enactment and the initial emphasis on implementation, the early enforcement records reveal a common prevalence of cases not relating to serious distortions of competition. ${ }^{2}$ In its 1998 reports on progress toward accession, the first round of annual peer reviews, the European Commission highlights outstanding gaps in the antitrust legislation of each candidate country and recommends a general shift of focus toward investigating hardcore cartels and important mergers. The individual assessments also broadly converge on shortcomings in institutional design, enforcement capacity and expertise, as well as on the need for a qualitative leap in the area of state aid control. As the accession preparations advance, the respective national frameworks are more closely aligned with the acquis communautaire and reflect the parallel evolution of EU competition rules.

Table 1: Enactment of Competition Legislation and Subsequent Amendments

\begin{tabular}{cccccccccccccc}
\hline Country & 1990 & 1991 & 1992 & 1993 & 1994 & 1995 & 1996 & 1997 & 1998 & 1999 & 2000 & 2001 & 2002 \\
\hline $\mathrm{BG}$ & & $\star$ & $\sim$ & & & & & & 0 & & & $\sim$ & $\sim$ \\
$\mathrm{CZ}$ & & $\star$ & $\sim$ & & & & $\circ$ & & & & $\sim$ & $\circ$ & $\sim$ \\
$\mathrm{EE}$ & & & & $\star$ & & $\sim$ & & & $\circ$ & $\sim$ & $\sim$ & $\circ$ & $\sim$ \\
$\mathrm{HU}$ & $\star$ & & & & & & & 0 & & $\sim$ & & $\circ$ & $\sim$ \\
$\mathrm{PL}$ & $\star$ & $\sim$ & & & & $\circ$ & $\sim$ & $\sim$ & & $\sim$ & $\sim$ & $\circ$ & $\sim$ \\
$\mathrm{SI}$ & & & $\star$ & & & & & & & $\circ$ & $\sim$ & $\sim$ & $\sim$ \\
$\mathrm{SK}$ & & $\star$ & & & & $\circ$ & & $\sim$ & & & $\sim$ & $\circ$ & $\sim$ \\
\hline
\end{tabular}

Note: $\star / \circ / \sim$ indicate year of initial law adoption/amendment with significant changes/amendment with minor changes, respectively.

Source: Dutz and Vagliasindi (2000) and Competition Authorities' Annual Reports.

A chronological overview of legislative developments with regard to competition policy in the respective countries is provided in table 1. Stylized details regarding the scope of improvements are listed in the appendix. In each of the seven countries antitrust legislation has undergone successive amendments, taking into account the initial enforcement experience and relevant developments in EU practice. Typically, statutory modifications have redefined the

\footnotetext{
${ }^{2}$ Transition economies' initial experience with competition policy implementation has been analyzed by Fingleton et al. (1996), centering on the Czech Republic, Hungary, Poland and the Slovak Republic, and Djankov and Hoekman (1997), focusing on Bulgaria. Both studies conclude that the bulk of enforcement activity has been directed at unfair trade practices rather than hardcore antitrust violations and find scope for more deterring penalties.
} 
scope of prohibited restrictive agreements, stipulating explicit references to vertical as well as to horizontal concerted practices and introducing several block exemptions. Further fine-tuning has resulted in legislative convergence on a number of fundamental principles. Specifically, the prohibition of hardcore restrictions irrespective of market power, the possibility for ex officio sector-wide inquiry and the codification of supply-side substitutability in the definition of relevant markets have been incorporated in the respective national legislations. Accordingly, the refinement of national competition laws reveals a general trend toward greater differentiation between market power and market share. This important notional distinction has been reflected in revised guidelines for assessment of market dominance and economic concentrations, respectively. Regulations pertaining to abuse of a dominant position have placed stronger emphasis on the undertaking's ability to prevent effective competition in the relevant market and to behave, to a great extent, independently of its competitors, customers and suppliers. Similarly, rationality in the control of concentrations has motivated a move from market share to turnover-based notification thresholds in most countries. The respective grace margins for concentrations and agreements of minor importance have typically been adjusted upward, indicating a shift toward priority treatment of hardcore violations. In the same vein, jurisdictional improvements have targeted the actual capability to influence the state of competition in a particular market, extending the coverage of competition rules to public entities, companies with special or exclusive rights and all associations, irrespective of their legal status. Operational modifications have also enabled competition authorities to grant conditional approvals and issue negative clearance, alleviating the case load and ensuring greater legal certainty for undertakings. In parallel, policy advocacy initiatives have strived to build a competition culture and reinforce the credibility of both substantive and procedural law. In each of the studied countries, competition agencies' advisory opinions on draft laws, governmental decisions and privatization strategies have fostered the elimination of regulations that distort market competition or impose barriers to entry.

On the whole, normative and operational improvements have introduced clearer definitions of competences, procedural rules and penalty provisions, ensuring further alignment with EU standards and practice. Clearly, the enhanced level of sophistication has been aimed at improving regulatory precision and ensuring that enforcement capacity would not be overwhelmed by infringements of minor importance. Annual peer screening exercises, in the framework of preparations for EU membership, have also contributed to achieving adequate harmonization of national legislations with the acquis communautaire. Nevertheless, although legislative amendments aimed at EU-compatibility have ensured a degree of uniformity on fundamental principles, notable differences across national frameworks remain on specific technical aspects. 
Besides asymmetrical enactment timeframes, the refined legal frameworks maintain a level of heterogeneity in stipulated thresholds, deadlines and penalties. As with trade barriers, the focus of antitrust investigations inevitably varies along both the industry and country dimensions, as well as over time. Unfortunately, quantifying competition policy implementation accordingly proves impossible, especially at higher levels of sectoral disaggregation. However, even if a particular industry has not been directly affected by investigations or stringent notification obligations, firms may be disciplined by greater awareness of potential penalties through competition advocacy and effective enforcement in other sectors of the economy. The present study relies on capturing the overall signaling effect of competition policy implementation on the basis of cross-country and intertemporal variations in enforcement and advocacy activities.

\section{Empirical Framework}

Our empirical investigation is based on an approach to mark-up estimation developed by Roeger (1995) that builds on a methodology pioneered by Hall (1988). In the absence of input and output market rigidities, competing firms price homogenous products at marginal cost. By contrast, profit maximization in an imperfectly competitive setting would drive a wedge between the value of marginal product and the corresponding factor cost. ${ }^{3}$ As shown by Hall (1988), the price-cost margin can be estimated from the relationship between contemporaneous fluctuations in output and average factor input.

Consider firm $i$ operating in industry $j$ at time $t$ according to a standard production function, homogeneous of degree $\gamma$ :

$$
Y_{i j t}=A_{i j t} F\left(L_{i j t}, M_{i j t}, K_{i j t}\right)
$$

In the adopted notation $A, L, M$ and $K$ stand for Hicks-neutral technical progress, labor, material inputs and capital, respectively. ${ }^{4}$ Under the current specification, the technical progress term can accommodate both inter-industry heterogeneity and firm-specific differences in technology. Logarithmic differentiation of the production function yields:

$$
\left(\frac{d Y}{Y}\right)_{i j t}=\left(\frac{\partial Y}{\partial L} \frac{d L}{Y}+\frac{\partial Y}{\partial M} \frac{d M}{Y}+\frac{\partial Y}{\partial K} \frac{d K}{Y}+\frac{d A}{A}\right)_{i j t}
$$

\footnotetext{
${ }^{3}$ In the assumed Cobb-Douglas functional form, there is a uniform gap between each input's cost and respective marginal product.

${ }^{4}$ Following Domowitz et al. (1988), Norrbin (1993) and Oliveira-Martins, Pilat, and Scarpetta (1996), the production function is extended to incorporate material inputs and defined over sales, rather than value added. In cases where a significant portion of variable cost is attributed to intermediate inputs, their omission would cause an upward bias in the mark-up estimates. Moreover, as pointed out by Basu and Fernald (1997), value added is a problematic proxy for output in the absence of perfect competition.
} 
Assuming Cournot behavior in imperfectly competitive product markets, the partial derivatives with respect to the factors of production can be derived from the first-order conditions for profit maximization. ${ }^{5}$

$$
\left(\frac{\partial Y}{\partial N}\right)_{i j t}=\left[\frac{1}{1+\left(\frac{Y_{i j t}}{P_{j t}} \frac{\partial P_{j t}}{\partial Y_{i j t}}\right)}\right]\left(\frac{P_{N}}{P}\right)_{j t}=\mu_{i j t}\left(\frac{P_{N}}{P}\right)_{j t}, \text { where } N=L, M, K
$$

Market power enables firms to set the value of each input's marginal product, $P_{j t}(\partial Y / \partial N)_{i j t}$, above the respective factor cost $P_{N j t}$. Retaining a general formulation for the production function's degree of homogeneity, the inputs' shares in total revenue sum to $(\gamma / \mu)$, where $\gamma$ - the scale parameter - does not necessarily equal one. ${ }^{6}$ Denoting logarithmic differences with lower case letters, substituting for the partial derivatives and rearranging terms yields an extended version of the method pioneered by Hall (1988):

$$
\begin{aligned}
(d y-d k)_{i j t} & =\mu_{i j t}\left[\alpha_{L}(d l-d k)+\alpha_{M}(d m-d k)\right]_{i j t}+\left(\gamma_{i j t}-1\right) d k_{i j t}+d a_{i j t}, \text { with } \\
\mu \alpha_{N} & =\mu \frac{P_{N}}{P} \frac{N}{Y}=\frac{\partial Y}{\partial N} \frac{N}{Y}
\end{aligned}
$$

While this variant of the original methodology allows separating the mark-up and scale coefficients, it does not avoid the inherent endogeneity problem. Proper estimation of equation 4 depends on the availability of suitable instrumental variables to address the correlation between unobservable productivity shocks and input choices. As suggested by Levinsohn (1993), fixed effects estimation could be used if the nature of the endogeneity is assumed to be constant over time. In turn, Roeger (1995) applies Hall's reasoning to the corresponding cost function and uses the interaction of the primal and dual approaches to derive a testable equation in nominal terms. Firm $i$ minimizes cost according to:

$$
C\left(P_{L j t}, P_{M j t}, P_{K j t}, Y_{i j t}, A_{i j t}\right)=\min _{L, M, K}\left\{\left(P_{L} L_{i}+P_{M} M_{i}+P_{K} K_{i}\right)_{j t} \mid A_{i j t} F\left(L_{i j t}, M_{i j t}, K_{i j t}\right)=Y_{i j t}\right\}
$$

The linear cost function is homogeneous of degree 1 in $L_{i j t}, M_{i j t}$ and $K_{i j t}$ and can be expressed in terms of unit cost as $Z\left(P_{L j t}, P_{M j t}, P_{K j t}\right)=C\left(P_{L j t}, P_{M j t}, P_{K j t}, 1\right)$. As $F($.$) is homogeneous of$ degree $\gamma$ in the respective factor inputs, $C($.$) is homogeneous of degree \frac{1}{\gamma}$ in $F($.$) . By Euler's$ rule $\frac{\partial C}{\partial Y}=\frac{1}{\gamma} \frac{C}{Y}$ and the corresponding expression for marginal cost is:

$$
\left(\frac{\partial C}{\partial Y}\right)_{i j t}=M C_{i j t}=\frac{1}{\gamma_{i j t}} \frac{Y_{i j t}^{\left(1 / \gamma_{i j t}-1\right)}}{A_{i j t}^{1 / \gamma_{i j t}}} Z\left(P_{L j t}, P_{M j t}, P_{K j t}\right)
$$

\footnotetext{
${ }^{5}$ Likewise, the first-order conditions for cost minimization imply $(\partial Y / \partial N)_{i j t}=P_{N} / \lambda$. By the Envelope Theorem $\lambda=(\partial C / \partial Y)_{i j t}$, the marginal cost of production. Thus, $(\partial Y / \partial N)_{i j t}=\mu_{i j t}\left(P_{N} / P\right)_{j t}$

${ }^{6}$ The production function $Y=A L^{a} M^{b} K^{c}$ is homogeneous of degree $\gamma$, so $\frac{\partial Y}{\partial L} \frac{L}{Y}+\frac{\partial Y}{\partial M} \frac{M}{Y}+\frac{\partial Y}{\partial K} \frac{K}{Y}=a+b+c=\gamma$. Substituting for the partial derivatives from the first-order conditions yields $\frac{P_{L}}{P} \frac{L}{Y}+\frac{P_{M}}{P} \frac{M}{Y}+\frac{P_{K}}{P} \frac{K}{Y}=\frac{\gamma}{\mu}$
} 
Making use of Shephard's lemma, logarithmic differentiation of equation 6 yields:

$$
\begin{aligned}
d m c_{i j t} & =\left(\frac{1}{\gamma_{i j t}}-1\right) d y_{i j t}-\frac{1}{\gamma_{i j t}} d a_{i j t}+\frac{\mu_{i j t}}{\gamma_{i j t}}\left(\alpha_{L i} d p_{L}+\alpha_{M i} d p_{M}+\alpha_{K i} d p_{K}\right)_{j t}, \text { with } \\
\frac{\mu}{\gamma} \alpha_{N} & =\frac{N P_{N}}{\gamma Y \frac{\partial C}{\partial Y}}=\frac{N P_{N}}{C}=\frac{\partial C}{\partial P_{N}} \frac{P_{N}}{C}=\frac{\partial Z}{\partial P_{N}} \frac{P_{N}}{Z}
\end{aligned}
$$

Taking the difference between the respective movements in output price and in marginal cost, and substituting for the technological change term in equation 4 , we obtain a convenient expression in nominal values: ${ }^{7}$

$$
\left(d y_{i}+d p-d k_{i}-d p_{K}\right)_{j t}=\frac{\mu_{i j t}}{\gamma_{i j t}}\left[\alpha_{L i}\left(d l_{i}+d p_{L}-d k_{i}-d p_{K}\right)+\alpha_{M i}\left(d m_{i}+d p_{M}-d k_{i}-d p_{K}\right)\right]_{j t}
$$

It is straightforward to derive the equivalent expression in terms of the Lerner index, $(1-\gamma / \mu)$, as in Roeger (1995). Denoting the left-hand side of equation 8 as $d q$ and the right-hand side as $d x$, we obtain a simple testable equation, which we extend with additional interaction terms to study the effects of trade and antitrust regimes:

$$
d q_{i j t}=\beta_{1} d x_{i j t}+\beta_{2} d x_{i j t} \times I M P_{j t}+\beta_{3} d x_{i j t} \times A T R_{c t}+\beta_{4} d x_{i j t} \times G R W_{c t}+\tau_{i}+\epsilon_{i j t}
$$

As the productivity shocks are eliminated by substitution in the interaction of the primal and dual approaches, a non-zero error term in equation 9 would capture measurement error that is likely to stem from inadequate accounting for the inputs' true utilization levels. To assess the effects of trade and competition policy reforms on firms' price-cost margins, we interact $d x$ with sector-level data on tariff protection, $I M P_{j t}$, and country-level measures of antitrust enforcement, $A T R_{c t}$. Mindful of the difficulty to comprehensively quantify multi-dimensional import and antitrust regimes, we use two alternative proxies for each policy instrument. Tariff protection is computed at the four-digit level of NACE industrial classification and is reflected by applied MFN rates and trade-weighted actual duties. Competition policy implementation is proxied by the number of final instance decisions delivered by the respective national authorities and an index developed by the EBRD. The alternative import protection and antitrust variables are included separately and in respective combinations in equation 9 to capture any differences between the primal and dual productivity decompositions that are not explained by market power. Real GDP growth is included as an additional interaction term to account for cyclical effects. ${ }^{8}$ Time-invariant firm-specific characteristics, such as managers' abilities or sunk costs,

\footnotetext{
${ }^{7}$ The derivation of equations 7 and 8 is underpinned by the assumption that $\mu$ and $\gamma$ remain constant within the period of differentiation. See Joergensen and Hylleberg (1998) for a discussion and an alternative derivation using the definition of average mark-up. A comparative analysis of the primal and dual approaches is presented in Kee (2004).

${ }^{8}$ For conciseness, we do not report the results from the regressions using individual interaction terms. The point estimates are qualitatively the same.
} 
are captured by $\tau_{i}$. Finally, we also include industry and year fixed effects to control for unobserved shocks and shifts over time.

A number of critical considerations regarding our methodology are in order. An important tradeoff between the approaches of Hall (1988) and Roeger (1995) is the ability to estimate returns to scale directly versus minimizing endogeneity issues and measurement bias, respectively. Estimating mark-ups with the former method is hindered by data requirements that become virtually unattainable at a higher level of sectoral disaggregation. Besides appropriate deflators for output, capital and materials, one needs to find suitable instruments to address the endogeneity resulting from potential correlation between unobserved demand or productivity shocks and the individual firm's input choices. Considerable firm heterogeneity within a single sector would imply a lot of noise when aggregate price indexes and instruments are applied to accounting figures. By introducing a cost-based expression for the unobservable technological change, Roeger (1995) avoids the problem of inadequate instruments and overcomes the issue of finding good deflators. ${ }^{9}$ Clearly, ignoring the presence of increasing (decreasing) returns to scale would lead to a downward (upward) bias in the mark-up estimates. However, any attempt to compute the influence of non-constant returns to scale would raise additional questions regarding the appropriate functional form and estimation technique. ${ }^{10}$ As long as the mark-up estimates are consistently biased, the corresponding intertemporal relationship should be unaffected and would allow us to adequately capture the impact of import protection and antitrust enforcement. This amounts to making the assumption that over the studied period companies did not experience significant downsizing or rapid growth. For empirical tractability, the literature on mark-up estimation typically assumes that firms within the same industry face identical productivity shocks to inputs and apply the same mark-up, which is constant in a given period. How reasonable these assumptions are depends crucially on the exact nature of the panel data set and the hypotheses tested. Finally, a shortcoming of the data derived from financial statements of multi-product firms, a considerable portion of our sample, is the inability to disentangle figures corresponding to individual products. Therefore, we must map product-level tariffs into the respective four-digit NACE industries and study more broadly defined structures than what is typically likely to qualify as the relevant market.

\footnotetext{
${ }^{9}$ However, the transformation of book value capital figures into current replacement cost implies recourse to an aggregate price index for both approaches. This issue is present in all estimations based on accounting data.

${ }^{10}$ Dobrinsky et al. (2004) find evidence of nearly constant returns to scale in Bulgarian and Hungarian manufacturing over the period 1995-2001, but caution that firm heterogeneity with respect to production scale may lead to important bias under the assumption of a uniform mark-up for a group of firms.
} 


\section{Data and Measurement Issues}

\section{Data}

Standardized annual company accounts were obtained from the Amadeus database maintained by Bureau van Dijk Electronic Publishing. This unique pan-European dataset constitutes a compendium of harmonized financial statements, based on registered filings with the respective national statistical offices. We constrain our sample to the unconsolidated accounts of manufacturing firms in Bulgaria, the Czech Republic, Estonia, Hungary, Poland, Slovenia and the Slovak Republic. The available data constitute an unbalanced panel of 25,267 predominantly large and medium-sized enterprises spanning the period 1998-2002, after differencing. Summary statistics of the variables derived from company accounts are reported in table 2.

Table 2: Summary Statistics

\begin{tabular}{lrrrrrrr}
\hline & \multicolumn{1}{c}{ BG } & \multicolumn{1}{c}{ CZ } & \multicolumn{1}{c}{ EE } & HU & PL & SI & SK \\
\hline Turnover & 1008.040 & 12871.830 & 975.407 & 7536.222 & 14676.910 & 2954.916 & 14635.760 \\
& $(9975.009)$ & $(52379.480)$ & $(3311.844)$ & $(74867.650)$ & $(54669.980)$ & $(19586.770)$ & $(28334.820)$ \\
Tangible Fixed Assets & 483.883 & 4722.303 & 269.682 & 1816.218 & 4862.251 & 1346.853 & 6665.959 \\
& $(4455.636)$ & $(32010.090)$ & $(1323.589)$ & $(16085.500)$ & $(20635.850)$ & $(7271.496)$ & $(18099.540)$ \\
Material Costs & 533.260 & 10182.330 & 648.013 & 5268.212 & 6748.621 & 2106.955 & 12471.000 \\
& $(7347.057)$ & $(66478.150)$ & $(2372.941)$ & $(61147.240)$ & $(27036.970)$ & $(16379.920)$ & $(22537.900)$ \\
Personnel Costs & 144.391 & 2116.487 & 137.042 & 1247.863 & 1460.415 & 570.538 & 1809.094 \\
Employees & $(972.647)$ & $(38189.130)$ & $(386.322)$ & $(38835.340)$ & $(2671.714)$ & $(2562.975)$ & $(2530.738)$ \\
& 73 & 291 & 33 & 146 & 241 & 164 & 522 \\
\hline
\end{tabular}

Note: Standard deviations in parentheses; values expressed in thousands of dollars.

There is notable cross-country variation in average firm size, as captured by the number of employees. The considerably higher figure for the Slovak Republic indicates a certain sampling bias toward the largest firms in this country. Nevertheless, given the customs union with the Czech Republic and the independent antitrust enforcement in the two countries, including these firms would facilitate capturing the effect of competition policy implementation. ${ }^{11}$ While differences across countries are highlighted by the other variables as well, we must keep in mind the considerable inter and intra-industry heterogeneity that the average figures conceal. The dataset is fairly representative of industrial activity in the studied countries. A comparison with aggregate statistics on sales and personnel costs in manufacturing available from Euro-

\footnotetext{
${ }^{11}$ In fact, omitting Slovak firms from our cross-country regressions did not alter the estimates in a significant way.
} 
stat suggests that our data cover approximately 70 per cent of the respective total figures for Bulgaria, the Czech Republic, Estonia, Hungary, Poland and Slovenia. Only for the Slovak Republic representation is in the range of 20 per cent of total manufacturing turnover and personnel costs.

Product-level data on trade flows and applied customs tariffs, both on MFN basis and under preferential agreements, at six-digit HS level of disaggregation were obtained from the COMTRADE and WITS databases, respectively. The corresponding average import protection measures at four-digit NACE rev 1.1 level were computed using a detailed concordance between the two classifications available from Eurostat. In quantifying import barriers, we face a tradeoff between accounting for the preferential treatment of certain trading partners and minimizing bias. While MFN rates can be largely considered as exogenous, they do not capture the considerable volume of trade taking place at lower levels of protection across the studied countries. Trade-weighted tariffs reflect the preferential customs duties enforced under free trade agreements, using bilateral imports' share in total imports as respective weights. However, even in the short run trade flows are decisively influenced by the level of preferences granted and will produce a somewhat biased weighting. Accordingly, concurrent MFN and preferential tariff reductions would be reflected in sharper intertemporal declines of the computed average import barrier, whereas instances of increased protection would result in less pronounced increases.

Data on final instance decisions, covering cases of restrictive agreements, abuse of dominance and concentration authorizations, were taken from the respective antitrust authorities' annual reports. To reflect differences in economy size among the studied countries, the figures were scaled by the total number of domestic firms (in manufacturing, services, trade, construction and utilities) reported by Eurostat for the year 2000. As a purely quantitative measure of enforcement activity, the number of decisions would not capture well the differences across antitrust legislations or the seriousness of investigated anticompetitive practices. ${ }^{12}$ The alternative proxy for competition policy is an index developed by the EBRD, which takes into account both the legal and enforcement dimensions. The ranking of antitrust regimes is done on the basis of legislation, institutional framework, enforcement actions and efforts to reduce barriers to entry and promote a competitive environment. While the methodology is not described in detail, suggesting a possible degree of subjectivity in the assessment, the evolution of national competition policy frameworks in our sample is reported to reflect improved focus on market

\footnotetext{
${ }^{12}$ While the general presumption is that a stricter antitrust regime is associated with a higher number of decisions, the measure's interpretation remains somewhat problematic. A high quality of enforcement could be associated with more parsimonious decision-making, notably as a consequence of legislative fine-tuning.
} 
power, break-up of dominant conglomerates and reduction of entry restrictions. Unfortunately, the limited time variation of the index restricts its use to cross-country panel regressions.

\section{Measurement Issues}

The use of nominal values, rather than deflated ones, offers the advantage of avoiding poor proxies for the actual price levels of inputs and output. Nevertheless, some measurement error is inevitable, as company accounts data do not accurately reflect true factor utilization. Specifically, fluctuations in the average work time per employee or per physical capital employed are inadequately captured in financial statements. Besides actual flows of labor and capital services, ideally, we should also account for variations in the respective inputs' quality. Inaccurate measurement of true factor utilization will result in a cyclical component in the error term. To control for the cyclical impact in the regression, we introduce time fixed effects and the growth rate of GDP as an additional macroeconomic variable capturing variations in demand. Conventional accounting principles also deviate from economic reasoning in the treatment of durable capital inputs acquired by the firm. Although financial accounts offer the possibility to distribute the purchase cost of an asset throughout its useful life, the interest tied up in the acquisition typically is not recognized as a true economic cost. Similarly, any anticipated change in purchase price over the respective period is not reflected in the input's recorded value. Accordingly, we follow established practice in the literature and transform the book value of tangible fixed assets into the corresponding figure at current replacement cost, using a simplified rental price of capital:

$$
P_{K}=\left(r_{c t}+\delta_{t}\right) \times P_{c t}
$$

$P_{c t}$ is the country-level producer price index of industrial output taken from WIIW. Data on the real annual deposit rates in each country, $r_{c t}$, were obtained from the IFS database. The annual depreciation rate is captured by $\delta_{t}$. In constructing the user cost of capital, we inevitably face practical problems with the measurement of the three components: depreciation, tied-up interest and anticipated price change. Among the various rates of return suggested in the literature on user cost calculation, the deposit rate stands out as best suited for transitional economies with underdeveloped credit and securities markets. Moreover, a safe rate of return, such as that of government bonds, was unavailable in a consistent formulation for all countries. Similarly, although an index of investment goods prices may seem more appropriate for our purposes, inadequate country coverage severely constrained our choice. Due to data limitations and different accounting conventions regarding the useful lives of assets, we also assumed a 
uniform depreciation rate of $10 \%$ for all firms. Alternative values for the depreciation rate produced qualitatively similar results.

\section{Results}

To get a general idea of the two policy regimes' quantitative effects, we compute the average price-cost margins corresponding to the top and bottom quartiles of the relevant proxies. The lowest levels of import protection, both in MFN and trade-weighted terms, are associated with a mark-up of 6.3 percent. The reciprocal estimates at the tariff peaks are 19.6 and 14.3 percent, respectively. The average mark-ups at low levels of antitrust enforcement, as reflected by the number of final instance decisions and the EBRD index, stand at 6.1 and and 6.9 percent. However, due to insufficient observations at the lower quartile of the latter measure, the two sub-samples for that variable were defined at the median. Significant enforcement activity ensures pricing slightly below marginal cost in the case of final rulings, whereas the corresponding figure for the upper half of the EBRD ranking is 5.8 percent. In absolute terms, the difference between average mark-ups at the top and bottom quartiles is most pronounced for the number of decisions (17\%), followed by that corresponding to the MFN tariff (13.3\%). Unfortunately, the underlying distribution with respect to the EBRD index does not allow a similar comparison of the effects' magnitude. We also test for the significance of enacting major legislative amendments with regard to competition policy in the studied countries. Our findings indicate that, on average, price-cost margins have decreased by nearly 6 percent following the wave of improvements to the relevant national legal frameworks.

Pooling firms across countries and industries, we test for the overall effects of tariff protection and competition policy implementation on price-cost margins, as captured by the possible pairs of alternative variables. Controls for industry-specific and country-specific differences in mark-ups, as well as time fixed effects, are also incorporated in the regression. Point estimates for the respective combinations of alternative proxies are reported in table 3 along with the corresponding average effects. The estimation results suggest that mark-ups increase with higher import barriers and decrease with more intensive antitrust enforcement. In terms of magnitude, the distinct effects on firms' price-cost margins must be computed as the product of the point estimate and a certain value of the corresponding interaction variable. Using sample means of the particular proxies, a natural choice for an impact assessment, we find that, on average, the disciplining effect of competition policy implementation more than offsets the leeway afforded by tariff protection. ${ }^{13}$ This result largely holds at the respective extreme values, as well. The

\footnotetext{
${ }^{13}$ As an additional robustness check, we computed the crude mark-up observed directly from company ac-
} 
Table 3: Estimated Effects

\begin{tabular}{lcccc}
\hline & $(1)$ & $(2)$ & $(3)$ & $(4)$ \\
\hline EBRD index & - & - & -0.129 & -0.136 \\
& & & $(0.045)^{* * *}$ & $(0.045)^{* * *}$ \\
Final decisions & -0.051 & -0.053 & - & - \\
& $(0.025)^{*}$ & $(0.025)^{* *}$ & & \\
Antitrust Effect & $\mathbf{- . 0 4 0}$ & $\mathbf{- . 0 4 2}$ & $\mathbf{- 0 . 0 8 3}$ & $\mathbf{- 0 . 0 8 8}$ \\
MFN tariff & 0.192 & - & 0.192 & - \\
& $(0.064)^{* * *}$ & & $(0.063)^{* * *}$ & \\
Trade-weighted tariff & - & 0.104 & - & 0.112 \\
& & $(0.068)^{*}$ & & $(0.070)^{*}$ \\
Import Barrier Effect & $\boldsymbol{0 . 0 2 9}$ & $\boldsymbol{0 . 0 0 6}$ & $\boldsymbol{0 . 0 2 9}$ & $\boldsymbol{0 . 0 0 6}$ \\
$\triangle$ GDP & -0.315 & -0.311 & -0.362 & -0.362 \\
& $(0.098)^{* * *}$ & $(0.097)^{* * *}$ & $(0.103)^{* * *}$ & $(0.103)^{* * *}$ \\
Cyclical Effect & $\boldsymbol{0 . 0 0 8}$ & $\boldsymbol{0 . 0 0 7}$ & $\boldsymbol{0 . 0 0 9}$ & $\boldsymbol{0 . 0 0 9}$ \\
$R^{2}$ & 0.687 & 0.687 & 0.687 & 0.687 \\
Observations & 62784 & 62784 & 62784 & 62784 \\
\hline
\end{tabular}

Note: Robust standard errors in parentheses. */**/*** indicate significance at 10/5/1 per cent, respectively. Effects reported at sample means of the relevant interaction terms.

only exception is at the maxima where the effect of peak MFN rates exceeds that of antitrust enforcement, as reflected by both proxies. The joint significance of import and antitrust regimes suggests that trade liberalization alone may not create sufficient conditions for the containment and prevention of market power abuses in the process of economic transformation. As our study covers predominantly small economies, it is noteworthy that barriers to trade do not seem to dominate the importance of competition policy in influencing the pricing behavior of domestic firms. Trade liberalization over the studied period is captured by both the MFN and tradeweighted tariff variables - the respective declines in mean duties of 3.8 and 4.5 per cent suggest price-cost margin reductions of 0.7 and 0.5 per cent. Our estimates highlight that MFN import duties have a comparatively larger effect than the trade-weighted counterpart. In this respect, we must note that the latter variable reflects the presence of preferential rates and, due to the weighting, is susceptible to a downward bias in the measurement of import protection changes over time. Similarly, the impact of antitrust enforcement estimated using the EBRD index is larger than that suggested by the number of final instance decisions. This is consistent with the counts and regressed it on the same variables. The results are qualitatively analogous. Hausman tests strongly supported the appropriateness of fixed effects estimation in all specifications. We also controlled for possible endogeneity of antitrust enforcement activity to observed price-cost margins. A Durbin-Wu-Hausman test confirmed that the number of final instance decisions can be treated as exogenous. 
fact that qualitative aspects of the relevant national authorities' activities during the studied period, such as effective reduction of entry barriers and competition advocacy, presumably are better reflected in the former variable.

Table 4: Directional Prevalence of Trade

\begin{tabular}{|c|c|c|c|c|c|c|c|c|}
\hline \multirow[b]{2}{*}{$E B R D$ index } & \multicolumn{2}{|c|}{ Import-intensive } & \multicolumn{2}{|c|}{ Export-oriented } & \multicolumn{2}{|c|}{ Import-intensive } & \multicolumn{2}{|c|}{ Export-oriented } \\
\hline & - & - & - & - & $\begin{array}{c}-0.129 \\
(0.062)^{* *}\end{array}$ & $\begin{array}{c}-0.147 \\
(0.061)^{* *}\end{array}$ & $\begin{array}{l}-0.086 \\
(0.07)\end{array}$ & $\begin{array}{l}-0.085 \\
(0.071)\end{array}$ \\
\hline Final decisions & $\begin{array}{c}-0.082 \\
(0.037)^{* *}\end{array}$ & $\begin{array}{c}-0.085 \\
(0.037)^{* *}\end{array}$ & $\begin{array}{l}-0.034 \\
(0.027)\end{array}$ & $\begin{array}{l}-0.035 \\
(0.027)\end{array}$ & - & - & - & - \\
\hline Antitrust Effect & -0.068 & -0.071 & -0.024 & -0.025 & -0.08 & -0.091 & -0.055 & -0.054 \\
\hline$M F N$ tariff & $\begin{array}{c}0.382 \\
(0.196)^{*}\end{array}$ & - & $\begin{array}{c}0.168 \\
(0.073)^{* *}\end{array}$ & - & $\begin{array}{c}0.37 \\
(0.192)^{*}\end{array}$ & - & $\begin{array}{c}0.166 \\
(0.072)^{* *}\end{array}$ & - \\
\hline Trade-weighted tariff & - & $\begin{array}{c}0.460 \\
(0.118)^{* * *}\end{array}$ & - & $\begin{array}{l}-0.046 \\
(0.135)\end{array}$ & - & $\begin{array}{c}0.463 \\
(0.124)^{* * *}\end{array}$ & - & $\begin{array}{l}-0.047 \\
(0.136)\end{array}$ \\
\hline Import Barrier Effect & 0.049 & 0.021 & 0.027 & -0.003 & 0.047 & 0.021 & 0.027 & -0.003 \\
\hline$\triangle G D P$ & $\begin{array}{c}-0.410 \\
(0.110)^{* * *}\end{array}$ & $\begin{array}{c}-0.392 \\
(0.103)^{* * *}\end{array}$ & $\begin{array}{c}-0.383 \\
(0.140)^{* *}\end{array}$ & $\begin{array}{c}-0.393 \\
(0.134)^{* * *}\end{array}$ & $\begin{array}{c}-0.43 \\
(0.098)^{* * *}\end{array}$ & $\begin{array}{c}-0.426 \\
(0.092)^{* * *}\end{array}$ & $\begin{array}{c}-0.42 \\
(0.164)^{* *}\end{array}$ & $\begin{array}{c}-0.428 \\
(0.160)^{* *}\end{array}$ \\
\hline Cyclical Effect & 0.011 & 0.011 & 0.009 & 0.009 & 0.012 & 0.011 & 0.01 & 0.01 \\
\hline$R^{2}$ & 0.689 & 0.689 & 0.69 & 0.69 & 0.689 & 0.689 & 0.69 & 0.69 \\
\hline Observations & 19507 & 19507 & 20148 & 20148 & 19507 & 19507 & 20148 & 20148 \\
\hline Firms & 7976 & 7976 & 7907 & 7907 & 7976 & 7976 & 7907 & 7907 \\
\hline
\end{tabular}

Note: Robust standard errors in parentheses. ${ }^{*} / * * / * *$ indicate significance at $10 / 5 / 1$ per cent, respectively.

Effects reported at sample means of the relevant interaction terms.

For further insights on the role played by trade in the shaping of competitive markets, we split the sample according to the directional prevalence of actual flows in the five-year period. Our approach is motivated by endogeneity issues, as both import penetration and export figures are likely to be correlated with domestic productivity or demand shocks. The trade flows are measured in quantity terms in order to avoid any additional bias stemming from differences in price levels. Accordingly, we define four-digit NACE industries as import-intensive if the exports to imports ratio does not exceed 0.85 in any single year within the examined timespan. To qualify a manufacturing sector as export-oriented, its corresponding ratio must be no less than 1.15 throughout the period. ${ }^{14}$ The third category, characterized by very similar export and import flows, is likely to reflect strong re-exports or a high degree of product differentiation. Only the EBRD proxy for antitrust enforcement produced a statistically significant point estimate from this sub-sample. By and large, the results shown in table 4 confirm that

\footnotetext{
${ }^{14}$ We also experimented with a larger sample, including sectors that crossed the thresholds during the studied period, as well as with a cutoff at 1 . The results were qualitatively analogous - the estimated mean effects were only marginally lower.
} 
import tariff protection has a positive impact on mark-ups, whereas competition policy exerts a depressing effect of larger magnitude. The comparative differences between estimates obtained using alternative proxies are also maintained. In terms of statistical significance, the pricing behavior of firms in export-oriented industries appears fairly unaffected by either policy instrument. Only MFN tariff barriers are found to have a significant effect on price-cost margins in sectors that are successfully competing abroad. Incidentally, this is the only instance where the impact of import protection exceeds in magnitude that of antitrust enforcement, as reflected by the number of final instance decisions. Considering the predominantly regional focus of trade flows and preferences granted, this result may suggest some potential for further enhancing competitive pressure, albeit modestly, through multilateral liberalization. In this respect, it is important to note the limitations of efforts to discipline the pricing behavior of internationally competitive firms.

Table 5: Dynamic Effects of Antitrust Enforcement

\begin{tabular}{|c|c|c|c|c|c|c|}
\hline \multirow[b]{2}{*}{ Final decisions $_{(t-1)}$} & \multicolumn{2}{|c|}{ Full Sample } & \multicolumn{2}{|c|}{ Import-intensive } & \multicolumn{2}{|c|}{ Export-oriented } \\
\hline & $\begin{array}{c}-0.047 \\
(0.016)^{* * *}\end{array}$ & $\begin{array}{c}-0.048 \\
(0.016)^{* * *}\end{array}$ & $\begin{array}{c}-0.107 \\
(0.031)^{* * *}\end{array}$ & $\begin{array}{c}-0.110 \\
(0.031)^{* * *}\end{array}$ & $\begin{array}{l}-0.010 \\
(0.021)\end{array}$ & $\begin{array}{l}-0.010 \\
(0.021)\end{array}$ \\
\hline Antitrust Effect & -0.034 & -0.034 & -0.080 & -0.082 & -0.006 & -0.006 \\
\hline$M F N$ tariff & $\begin{array}{c}0.193 \\
(0.063)^{* * *}\end{array}$ & - & $\begin{array}{c}0.380 \\
(0.193)^{*}\end{array}$ & - & $\begin{array}{c}0.166 \\
(0.072)^{* *}\end{array}$ & - \\
\hline Trade-weighted tariff & - & $\begin{array}{c}0.101 \\
(0.067)^{*}\end{array}$ & - & $\begin{array}{c}0.449 \\
(0.117)^{* * *}\end{array}$ & - & $\begin{array}{l}-0.053 \\
(0.130)\end{array}$ \\
\hline Import Barrier Effect & 0.029 & 0.006 & 0.049 & 0.021 & 0.027 & -0.004 \\
\hline$\triangle G D P$ & $\begin{array}{c}-0.240 \\
(0.092)^{* *}\end{array}$ & $\begin{array}{c}-0.234 \\
(0.091)^{* *}\end{array}$ & $\begin{array}{c}-0.248 \\
(0.091)^{* *}\end{array}$ & $\begin{array}{c}-0.226 \\
(0.085)^{* *}\end{array}$ & $\begin{array}{c}-0.339 \\
(0.142)^{* *}\end{array}$ & $\begin{array}{c}-0.347 \\
(0.135)^{* *}\end{array}$ \\
\hline Cyclical Effect & 0.006 & 0.006 & 0.007 & 0.006 & 0.008 & 0.008 \\
\hline$R^{2}$ & 0.687 & 0.687 & 0.690 & 0.689 & 0.690 & 0.690 \\
\hline Observations & 62784 & 62784 & 19507 & 19507 & 20148 & 20148 \\
\hline
\end{tabular}

Note: Robust standard errors in parentheses. */**/*** indicate significance at 10/5/1 per cent, respectively. Effects reported at sample means of the relevant interaction terms.

As antitrust investigations and appeals could span over considerable periods of time, it is a priori unclear whether firms would be forward or backward looking with respect to final rulings, in adjusting their pricing behavior. Accordingly, we test for the presence of an intertemporal signaling effect of competition policy enforcement in both directions, using the number of final instance decisions with a one-year lead and lag, respectively. Our results lend strong support to the hypothesis of ex post correction of price-cost margins, indicating that, in general, the mere 
launching of proceedings is not perceived as a viable threat. ${ }^{15}$ The point estimates obtained with lagged figures are highly significant, both for the full sample and the import-competing subset, whereas the forward-looking counterparts are insignificant in all specifications. In terms of magnitude, while the average antitrust effect suggested by the entire sample is slightly below the one observed in the contemporaneous case, we find a more pronounced impact in importintensive sectors. The findings for export-oriented industries are also confirmed, notably the lack of statistically significant relationship to the number of decisions and the dominance of MFN import barriers' impact over antitrust enforcement activity.

We must also note that using the EBRD index as an explanatory variable may impose an unrealistic restriction on the regression. Being a ranking of antitrust enforcement at uniform increments, such a regressor would introduce an implicit assumption of unvarying difference across mark-ups corresponding to adjacent thresholds. In reality, there is no reason to expect that, on average, the pricing behavior of firms would alter by identical margins for each level upgrade attained by national competition policy regimes.

Table 6: Threshold Effects

\begin{tabular}{|c|c|c|c|c|c|c|c|c|}
\hline \multirow[b]{2}{*}{ EBRD Threshold 1} & \multicolumn{2}{|c|}{ Full Sample } & \multicolumn{2}{|c|}{ Import-intensive } & \multicolumn{2}{|c|}{ Export-oriented } & \multicolumn{2}{|c|}{ Imports $\approx$ Exports } \\
\hline & $\begin{array}{l}-0.021 \\
(0.059)\end{array}$ & $\begin{array}{l}-0.023 \\
(0.059)\end{array}$ & $\begin{array}{l}-0.033 \\
(0.106)\end{array}$ & $\begin{array}{l}-0.039 \\
(0.106)\end{array}$ & $\begin{array}{l}-0.015 \\
(0.078)\end{array}$ & $\begin{array}{l}-0.015 \\
(0.077)\end{array}$ & $\begin{array}{l}-0.021 \\
(0.104)\end{array}$ & $\begin{array}{l}-0.018 \\
(0.102)\end{array}$ \\
\hline EBRD Threshold 2 & $\begin{array}{c}-0.047 \\
(0.020)^{* *}\end{array}$ & $\begin{array}{c}-0.049 \\
(0.020)^{* *}\end{array}$ & $\begin{array}{c}-0.049 \\
(0.022)^{* *}\end{array}$ & $\begin{array}{c}-0.056 \\
(0.022)^{* *}\end{array}$ & $\begin{array}{l}-0.033 \\
(0.027)\end{array}$ & $\begin{array}{l}-0.032 \\
(0.027)\end{array}$ & $\begin{array}{c}-0.066 \\
(0.034)^{*}\end{array}$ & $\begin{array}{c}-0.067 \\
(0.033)^{*}\end{array}$ \\
\hline EBRD Threshold 3 & $\begin{array}{c}-0.167 \\
(0.077)^{* *}\end{array}$ & $\begin{array}{c}-0.161 \\
(0.077)^{* *}\end{array}$ & $\begin{array}{c}0.000 \\
(0.113)\end{array}$ & $\begin{array}{c}0.006 \\
(0.111)\end{array}$ & $\begin{array}{c}0.257 \\
(0.073)^{* * *}\end{array}$ & $\begin{array}{c}0.313 \\
(0.084)^{* * *}\end{array}$ & $\begin{array}{c}-0.295 \\
(0.156)^{* *}\end{array}$ & $\begin{array}{c}-0.293 \\
(0.156)^{* *}\end{array}$ \\
\hline$M F N$ tariff & $\begin{array}{c}0.189 \\
(0.062)^{* * *}\end{array}$ & - & $\begin{array}{c}0.365 \\
(0.192)^{*}\end{array}$ & - & $\begin{array}{c}0.166 \\
(0.073)^{* *}\end{array}$ & - & $\begin{array}{c}0.054 \\
(0.098)\end{array}$ & - \\
\hline Trade-weighted tariff & - & $\begin{array}{l}0.112 \\
(0.07)\end{array}$ & - & $\begin{array}{c}0.454 \\
(0.121)^{* * *}\end{array}$ & - & $\begin{array}{l}-0.038 \\
(0.141)\end{array}$ & - & $\begin{array}{c}0.034 \\
(0.119)\end{array}$ \\
\hline Import Barrier Effect & 0.028 & 0.006 & 0.047 & 0.021 & 0.027 & -0.003 & 0.009 & 0.002 \\
\hline$\triangle G D P$ & $\begin{array}{c}-0.355 \\
(0.111)^{* * *}\end{array}$ & $\begin{array}{c}-0.353 \\
(0.112)^{* * *}\end{array}$ & $\begin{array}{c}-0.423 \\
(0.107)^{* * *}\end{array}$ & $\begin{array}{c}-0.421 \\
(0.103)^{* * *}\end{array}$ & $\begin{array}{c}-0.412 \\
(0.172)^{* *}\end{array}$ & $\begin{array}{c}-0.418 \\
(0.170)^{* *}\end{array}$ & $\begin{array}{l}-0.245 \\
(0.152)\end{array}$ & $\begin{array}{l}-0.245 \\
(0.153)\end{array}$ \\
\hline Cyclical Effect & 0.008 & 0.008 & 0.011 & 0.011 & 0.009 & 0.01 & 0.005 & 0.005 \\
\hline$R^{2}$ & 0.688 & 0.688 & 0.69 & 0.689 & 0.69 & 0.69 & 0.686 & 0.687 \\
\hline Observations & 62784 & 62784 & 19507 & 19507 & 20148 & 20148 & 23129 & 23129 \\
\hline
\end{tabular}

Note: Robust standard errors in parentheses. */**/*** indicate significance at 10/5/1 per cent, respectively.

A more flexible regression, allowing for asymmetrical threshold effects, reveals that such an assumption is indeed inaccurate. We find that a move from the lowest of the four thresholds in

\footnotetext{
${ }^{15}$ This could also reflect a learning process within the respective competition authorities, resulting in more focused investigations at a later stage.
} 
our sample to the second is not associated with a statistically significant difference in price-cost margins. Nevertheless, firms' pricing behavior is significantly affected by further improvements in antitrust enforcement. Evolving on to the third and fourth levels of competition policy effectiveness reduces mark-ups by about 5 and 16 per cent, respectively. An interesting pattern emerges from the two extreme subsets defined by the exports to imports ratio, while results for the intermediate case are broadly in line with those for the full sample. Estimates for the importcompeting category confirm that a degree of maturity corresponding to the third threshold is associated with a depressing impact on price-cost margins, but indicate no change when the next level is reached. By contrast, regressions based on the export-oriented subset yield a positive and statistically significant estimate for the marginal effect of the highest threshold. A plausible explanation for this result may be that internationally competitive firms benefit from enhanced competition in their material input markets, while remaining less susceptible to indirect threats of strengthened antitrust enforcement. Our findings lend some support to the premise that competition rules should be aligned to domestic economic realities. The robust responsiveness of import-competing firms' mark-ups to more competitive conditions suggests that a direct comprehensive transposition of European standards in antitrust legislation from the outset of transition might have hampered enterprise restructuring and development in the studied economies. In this respect, the delayed harmonization of national legislations with the Community blueprint in the area of state aid, observed in all countries, may not be entirely unjustified.

Country-specific mark-up estimates for each manufacturing sector with sufficient observations are reported in table 7 . There is notable variation across countries, as well as across industries. The price-cost margins compare favorably with estimates reported in earlier studies. Using a sample of Bulgarian manufacturing firms between 1994 and 1998, Konings et al. (2005) compute mark-ups in the range of 20 to 40 percent and Dobrinsky et al. (2004) document margins of comparable magnitude for Bulgaria and Hungary over the period 1995-2001. The pairwise correlation across sectoral price-cost margins is relatively low, indicating that domestic market conditions have a non-negligible impact on firms' pricing behavior. Incidentally, the strongest (and statistically significant) systematic relationships are observed between the mark-up estimates for Bulgaria, Hungary and Slovenia. The respective rank correlations for the pairs Bulgaria-Hungary, Bulgaria-Slovenia and Hungary-Slovenia are 0.378, 0.515 and 0.436. It may not be unrealistic to attribute these figures to the similar levels of import protection, as well as the similar positions of Bulgaria and Slovenia in the EBRD ranking of antitrust enforcement regimes.

Notwithstanding the harmonization of balance sheet entries in the Amadeus database, dif- 
Table 7: Price-Cost Margins by Sector

\begin{tabular}{|c|c|c|c|c|c|c|c|}
\hline NACE Code & BG & $\mathrm{CZ}$ & $\mathrm{EE}$ & $\mathrm{HU}$ & PL & SI & SK \\
\hline 15 Food and beverages & $5^{* * *}$ & $6.7^{* * *}$ & $14.4^{* * *}$ & $28^{* * *}$ & $23.1 * * *$ & $5.4^{* * *}$ & 0.5 \\
\hline 17 Textiles & $24.9^{* * *}$ & $6.7^{* * *}$ & $25^{* * *}$ & $49.9^{* * *}$ & $24.3^{* * *}$ & $6.8^{* * *}$ & $30.4^{* * *}$ \\
\hline 18 Wearing apparel; fur & $36.4^{* * *}$ & $8.4^{* * *}$ & $10.5^{* * *}$ & $26.4^{* * *}$ & $61.9^{* * *}$ & $12.5^{* * *}$ & - \\
\hline 19 Leather, luggage and footwear & $22.9^{* * *}$ & $11.7^{* *}$ & $36.6^{* * *}$ & $43.9^{* *}$ & $26.7^{* * *}$ & $5.6^{* * *}$ & 4.3 \\
\hline 20 Wood, straw and plaiting materials & $15.2^{* * *}$ & $24^{* * *}$ & $6.6^{* * *}$ & $25.7^{* * *}$ & $23.4^{* * *}$ & $7.2^{* * *}$ & - \\
\hline 21 Pulp, paper and paper products & $11.6^{*}$ & $2.9^{* * *}$ & $50.9^{* * *}$ & $48.7^{* * *}$ & - & $8.7^{* * *}$ & $32.7^{* * *}$ \\
\hline 22 Publishing, printing and media & $51.3^{* * *}$ & $22.1^{* * *}$ & $9.3^{* * *}$ & $24.4^{* * *}$ & $55.2^{* * *}$ & $11.8^{*}$ & $36.7^{* * *}$ \\
\hline 23 Coke, refined petroleum products, nuclear fuel & $31.3^{* * *}$ & $18.4^{* * *}$ & - & $13.8^{* *}$ & - & $5.7^{* * *}$ & - \\
\hline 24 Chemicals and chemical products & $27.2^{* * *}$ & $18.6^{* * *}$ & $55.4^{* * *}$ & $77.9^{* * *}$ & $50.6^{* * *}$ & $4.4^{* * *}$ & 6.6 \\
\hline 25 Rubber and plastic products & $19.1^{* * *}$ & $18.6^{* * *}$ & $20.1^{* * *}$ & $57.2^{* * *}$ & $32.5^{* * *}$ & $14.9^{* * *}$ & $39.3^{* *}$ \\
\hline 26 Other non-metallic mineral products & $22.4^{* * *}$ & $22.4^{* * *}$ & $26.2^{* * *}$ & $20.6^{* * *}$ & $63.2^{* *}$ & $13.5^{* *}$ & $35.8^{* * *}$ \\
\hline 27 Basic metals & $27.7^{* * *}$ & $34^{* * *}$ & $17.1^{* * *}$ & $40^{* *}$ & $37.2^{* * *}$ & $15.7^{* *}$ & - \\
\hline 28 Fabricated metal products & $25^{* * *}$ & $6.1^{* * *}$ & $20.1^{* * *}$ & $32.3^{* * *}$ & $64.1^{* *}$ & $13.1^{* *}$ & $31.2^{*}$ \\
\hline 29 Machinery and equipment n.e.c. & $24.8^{* * *}$ & $11.2^{* *}$ & $21.4^{* * *}$ & $43.7^{* * *}$ & $41.3^{* * *}$ & $16.1^{* * *}$ & - \\
\hline 30 Office machinery and computers & $14.1^{* * *}$ & $67.1^{* * *}$ & $28.3^{* * *}$ & $21^{* * *}$ & $31.4^{* * *}$ & $5.9^{* * *}$ & - \\
\hline 31 Electrical machinery and apparatus n.e.c. & $31^{* * *}$ & $6.6^{* * *}$ & $5.1^{* * *}$ & $41.8^{* * *}$ & $24.4^{* * *}$ & $10.5^{* * *}$ & 13.7 \\
\hline 32 Radio, TV, and communication equipment & $35.2^{* * *}$ & $14.8^{* * *}$ & $4.1^{* * *}$ & $73.3^{* * *}$ & $61.7^{* *}$ & $7.9^{* * *}$ & $31.7^{* *}$ \\
\hline 33 Medical, precision, and optical instruments & $58.8^{* * *}$ & $31.7^{* * *}$ & $17.7^{* * *}$ & $70.1^{* * *}$ & $56.9^{* * *}$ & $9.2^{* * *}$ & - \\
\hline 34 Motor vehicles, trailers, and semi-trailers & $34.1^{* * *}$ & $23.2^{* * *}$ & $1^{* * *}$ & $29.7^{* * *}$ & $30.8^{* *}$ & $12.7^{* *}$ & $67.6^{* * *}$ \\
\hline 35 Other transport equipment & $28.8^{* * *}$ & - & $31.7^{* * *}$ & - & $27.5^{* * *}$ & $9^{* * *}$ & 29.5 \\
\hline 36 Furniture, manufacturing n.e.c. & $15.2^{* * *}$ & $3.9^{*}$ & $10.9^{* * *}$ & $11^{* * *}$ & $34.7 * * *$ & $12.6^{* * *}$ & $69.1^{* * *}$ \\
\hline
\end{tabular}

Note: Reported values correspond to $(P-M C) / M C .{ }^{*} / * * * * * *$ indicate significance at $10 / 5 / 1$ per cent, respectively.

ferences in reporting requirements and accounting conventions are likely to result in data idiosyncrasies across countries. To verify the robustness of the estimated relationships between price-cost margins and national import and antitrust regimes, we pool manufacturing firms in country-specific panels and replicate the regression on the separate sub-samples. Unfortunately, we cannot use the EBRD index in this context due to its limited variation over time.

The results are broadly in line with the findings based on the cross-country panel. A negative relationship between firms' mark-ups and the number of final instance decisions delivered by the national antitrust authorities is observed for each country, albeit statistically significant only in the case of Bulgaria and Hungary. On the whole, price-cost margins are positively related to import duties, with a more pronounced effect in the case of MFN tariffs. An interesting exception is observed in the case of Estonia where the estimated impact of trade-weighted rates, computed at the sample mean, exceeds in magnitude its counterpart obtained using MFN figures. This is consistent with the fact that in the presence of preferential trade agreements, by construct, the former variable attenuates a tariff barrier increase and overrates a respective 
Table 8: Estimated Effects by Country

\begin{tabular}{|c|c|c|c|c|c|c|c|}
\hline & BG & $\mathrm{CZ}$ & $\mathrm{EE}$ & $\mathrm{HU}$ & PL & SI & SK \\
\hline Final decisions & $\begin{array}{c}-1.484 \\
(0.700)^{* *}\end{array}$ & $\begin{array}{l}-1.008 \\
(1.832)\end{array}$ & $\begin{array}{l}-0.067 \\
(0.054)\end{array}$ & $\begin{array}{c}-0.168 \\
(0.093)^{*}\end{array}$ & $\begin{array}{l}-0.243 \\
(4.105)\end{array}$ & $\begin{array}{l}-0.086 \\
(0.115)\end{array}$ & $\begin{array}{l}-0.075 \\
(0.11)\end{array}$ \\
\hline Antitrust Effect & -0.299 & -0.179 & -0.14 & -0.394 & -0.037 & -0.023 & -0.42 \\
\hline$M F N$ tariff & $\begin{array}{c}0.512 \\
(0.195)^{* *}\end{array}$ & $\begin{array}{c}0.307 \\
(0.156)^{*}\end{array}$ & $\begin{array}{c}0.084 \\
(0.032)^{* *}\end{array}$ & $\begin{array}{c}0.465 \\
(0.137)^{* * *}\end{array}$ & $\begin{array}{c}0.221 \\
(0.127)^{*}\end{array}$ & $\begin{array}{c}0.042 \\
(0.143)\end{array}$ & $\begin{array}{c}1.944 \\
(0.514)^{* * *}\end{array}$ \\
\hline Import Barrier Effect & 0.109 & 0.019 & 0.001 & 0.055 & 0.08 & 0.005 & 0.147 \\
\hline$\triangle G D P$ & $\begin{array}{c}0.252 \\
(0.553)\end{array}$ & $\begin{array}{c}0.563 \\
(1.304)\end{array}$ & $\begin{array}{l}-0.103 \\
(0.42)\end{array}$ & $\begin{array}{c}-0.923 \\
(0.353)^{* *}\end{array}$ & $\begin{array}{c}1.908 \\
(2.128)\end{array}$ & $\begin{array}{c}0.068 \\
(0.228)\end{array}$ & $\begin{array}{c}1.57 \\
(0.912)\end{array}$ \\
\hline Cyclical Effect & -0.004 & -0.0005 & -0.001 & 0.04 & 0.0004 & -0.005 & -0.028 \\
\hline$R^{2}$ & 0.538 & 0.620 & 0.576 & 0.635 & 0.558 & 0.781 & 0.548 \\
\hline Final decisions & $\begin{array}{c}-1.263 \\
(0.807)^{*}\end{array}$ & $\begin{array}{l}-1.061 \\
(1.843)\end{array}$ & $\begin{array}{l}-0.069 \\
(0.054)\end{array}$ & $\begin{array}{c}-0.161 \\
(0.091)^{*}\end{array}$ & $\begin{array}{l}-0.107 \\
(4.08)\end{array}$ & $\begin{array}{l}-0.093 \\
(0.119)\end{array}$ & $\begin{array}{l}-0.048 \\
(0.115)\end{array}$ \\
\hline Antitrust Effect & -0.255 & -0.188 & -0.144 & -0.378 & -0.016 & -0.024 & -0.269 \\
\hline Trade-weighted tariff & $\begin{array}{l}0.048 \\
(0.15)\end{array}$ & $\begin{array}{c}0.211 \\
(0.142)\end{array}$ & $\begin{array}{c}2.952 \\
(0.659)^{* * *}\end{array}$ & $\begin{array}{c}0.546 \\
(0.049)^{* * *}\end{array}$ & $\begin{array}{c}0.567 \\
(0.195)^{* * *}\end{array}$ & $\begin{array}{c}0.017 \\
(0.099)\end{array}$ & $\begin{array}{l}-0.296 \\
(0.891)\end{array}$ \\
\hline Import Barrier Effect & 0.005 & 0.006 & 0.005 & 0.03 & 0.038 & 0.0004 & -0.007 \\
\hline$\triangle G D P$ & $\begin{array}{c}0.193 \\
(0.555)\end{array}$ & $\begin{array}{c}0.602 \\
(1.312)\end{array}$ & $\begin{array}{l}-0.11 \\
(0.42)\end{array}$ & $\begin{array}{c}-0.87 \\
(0.359)^{* *}\end{array}$ & $\begin{array}{c}1.815 \\
(2.102)\end{array}$ & $\begin{array}{c}0.058 \\
(0.231)\end{array}$ & $\begin{array}{c}1.961 \\
(0.960)\end{array}$ \\
\hline Cyclical Effect & -0.003 & -0.001 & -0.001 & 0.038 & 0.0004 & -0.004 & -0.034 \\
\hline$R^{2}$ & 0.536 & 0.620 & 0.575 & 0.635 & 0.558 & 0.781 & 0.542 \\
\hline Observations & 20270 & 8000 & 5959 & 10082 & 5641 & 12340 & 441 \\
\hline
\end{tabular}

Note: Robust standard errors in parentheses. */**/*** indicate significance at 10/5/1 per cent, respectively. Effects reported at sample means of the relevant interaction terms.

decline. Over the studied period, Estonia introduced non-zero MFN duties on a number of products concentrated solely in the food processing industry. Accordingly, the import barrier effect estimated on the basis of this variable is the lowest across all countries. The negative relationship obtained using trade-weighted duties for the Slovak Republic is probably due to the very limited number of observations. Unfortunately, while the customs union between the Czech and the Slovak Republics makes an interesting case for investigation, the considerable discrepancy in sample sizes does not allow us to draw any meaningful conclusions. Despite ample empirical evidence that price-cost margins vary over the business cycle, there is a deficiency of sound theoretical predictions regarding the direction of the mark-up's variation. While, for the most part, our country-specific estimates suggest a positive relationship to the business cycle, only the counter-cyclical results are statistically significant and confirm the earlier findings based on the cross-country panel. 


\section{Conclusion}

This paper draws on a rich firm-level dataset to analyze the role and interaction of trade and competition policies in the shaping of competitive markets across Central and Eastern Europe. Using alternative proxies, we find that, on average, tariff protection has a positive effect on mark-ups, whereas antitrust enforcement has a depressing impact of larger magnitude. As our study covers mostly small economies, it is noteworthy that barriers to trade do not seem to dominate the importance of competition policy in influencing the pricing behavior of domestic firms. The joint significance of import and antitrust regimes suggests that trade liberalization alone may not create sufficient conditions for the containment and prevention of market power abuses in the process of economic transformation. We must also recognize the limitations of efforts to discipline the pricing behavior of internationally competitive firms, consistently highlighted in our results.

\section{References}

BAsu, S., And J. G. Fernald (1997): "Aggregate productivity and aggregate technology," International Finance Discussion Papers 593, Board of Governors of the Federal Reserve System (U.S.).

Bottasso, A., And A. Sembenelli (2001): "Market power, productivity and the EU Single Market Program: Evidence from a panel of Italian firms," European Economic Review, 45(1), $167-186$.

Djankov, S., and B. Hoekman (1997): "Competition Law in Post-Central Planning Bulgaria," CEPR Discussion Papers 1723, C.E.P.R. Discussion Papers.

Dobrinsky, R., G. Körösi, N. Markov, and L. Halpern (2004): "Firms' Price Markups and Returns to Scale in Imperfect Markets: Bulgaria and Hungary," William Davidson Institute Working Papers Series 2004-710, William Davidson Institute at the University of Michigan Stephen M. Ross Business School.

Domowitz, I., R. G. Hubbard, and B. C. Petersen (1988): "Market Structure and Cyclical Fluctuations in U.S. Manufacturing," NBER Working Papers 2115, National Bureau of Economic Research, Inc.

Dutz, M. A., And M. Vagliasindi (2000): "Competition Policy Implementation in Transition Economies: An Empirical Assessment," European Economic Review, 44, 762-772. 
Fingleton, J., E. Fox, D. Neven, And P. Seabright (1996): Competition Policy and the Transformation of Central and Eastern Europe. Centre for Economic Policy Research, London.

Hall, R. E. (1988): "The Relation between Price and Marginal Cost in U.S. Industry," Journal of Political Economy, 96(5), 921-47.

HARrison, A. E. (1994): "Productivity, imperfect competition and trade reform : Theory and evidence," Journal of International Economics, 36(1-2), 53-73.

Hoekman, B., And H. L. KeE (2003): "Imports, Entry, and Competition Law as Market Disciplines," Policy Research Working Paper Series 3031, The World Bank.

Joergensen, R. W., and S. Hylleberg (1998): "A Note on the Estimation of Markup Pricing in Manufacturing," Department of Economics, Working Papers 1998-6, Department of Economics, University of Aarhus.

KeE, H. L. (2004): "Estimating Productivity When Primal and Dual TFP Accounting Fail: An Illustration Using Singapore's Industries," Topics in Economic Analysis \& Policy, 4(1), 1193-1193.

Konings, J., P. Van Cayseele, and F. Warzynski (2001): "The dynamics of industrial mark-ups in two small open economies: does national competition policy matter?," International Journal of Industrial Organization, 19(5), 841-859.

(2005): "The Effects of Privatization and Competitive Pressure on Firms' Price-cost Margins: Micro Evidence from Emerging Economies," The Review of Economics and Statistics, $87(1), 124-134$.

Konings, J., And H. Vandenbussche (2005): "Antidumping Protection and Markups of Domestic Firms: Evidence from Firm Level Data," LICOS Discussion Papers 14104, LICOS Centre for Transition Economics, K.U.Leuven.

Krishna, P., And D. Mitra (1998): "Trade liberalization, market discipline and productivity growth: new evidence from India," Journal of Development Economics, 56(2), 447-462.

Levinsohn, J. (1993): "Testing the imports-as-market-discipline hypothesis," Journal of International Economics, 35(1-2), 1-22.

Norrbin, S. C. (1993): "The Relation between Price and Marginal Cost in U.S. Industry: A Contradiction," Journal of Political Economy, 101(6), 1149-64. 
Oliveira-Martins, J., D. Pilat, and S. Scarpetta (1996): "Mark-Up Ratios in Manufacturing Industries: Estimates for 14 OECD Countries," OECD Economics Department Working Papers 162, OECD Economics Department.

Roeger, W. (1995): "Can Imperfect Competition Explain the Difference between Primal and Dual Productivity Measures? Estimates for U.S. Manufacturing," Journal of Political Economy, 103(2), 316-30. 


\section{Appendix A}

Table 9: Trade Agreements - Chronology

\begin{tabular}{|c|c|c|c|c|c|c|c|}
\hline \multicolumn{2}{|c|}{ Partners } & \multirow{2}{*}{$\begin{array}{c}\text { Entry into force } \\
01 / 03 / 1992\end{array}$} & \multirow{2}{*}{$\begin{array}{l}\text { Type } \\
\text { FTA }\end{array}$} & \multicolumn{2}{|r|}{ Partners } & \multirow{2}{*}{$\begin{array}{c}\text { Entry into force } \\
01 / 03 / 1997\end{array}$} & \multirow{2}{*}{$\begin{array}{l}\text { Type } \\
\text { FTA }\end{array}$} \\
\hline CZ SK & $\mathrm{EC}$ & & & Slovenia & Lithuania & & \\
\hline Hungary & $\mathrm{EC}$ & $01 / 03 / 1992$ & FTA & CZ SK & Lithuania & $01 / 07 / 1997$ & FTA \\
\hline Poland & $\mathrm{EC}$ & 01/03/1992 & FTA & \multicolumn{2}{|c|}{ CEFTA (CZ, HU, PL, SK, SI, RO) } & 01/07/1997 & RTA \\
\hline CZ SK & EFTA & 01/07/1992 & FTA & Slovenia & Croatia & 01/01/1998 & FTA \\
\hline CEFTA & $\mathrm{CZ}, \mathrm{HU}, \mathrm{PL}, \mathrm{SK})$ & 01/03/1993 & RTA & Hungary & Israel & $01 / 02 / 1998$ & FTA \\
\hline Bulgaria & EFTA & 01/07/1993 & FTA & Poland & Israel & 01/03/1998 & FTA \\
\hline Hungary & EFTA & $01 / 10 / 1993$ & FTA & Hungary & Turkey & $01 / 04 / 1998$ & FTA \\
\hline Poland & EFTA & $15 / 11 / 1993$ & FTA & Poland & Latvia & 01/04/1998 & FTA \\
\hline Bulgaria & $\mathrm{EC}$ & $31 / 12 / 1993$ & FTA & Estonia & Turkey & 01/06/1998 & FTA \\
\hline \multicolumn{2}{|c|}{ BAFTA (EE, LV, LT) } & $01 / 04 / 1994$ & RTA & CZ SK & Turkey & $01 / 09 / 1998$ & FTA \\
\hline Estonia & $\mathrm{EC}$ & 01/01/1995 & FTA & Slovenia & Israel & $01 / 09 / 1998$ & FTA \\
\hline CZ SK & WTO & 01/01/1995 & MTS & Estonia & Faroe Islands & $01 / 12 / 1998$ & FTA \\
\hline Hungary & WTO & $01 / 01 / 1995$ & MTS & \multicolumn{2}{|c|}{ CEFTA (CZ, HU, PL, SK, SI, RO, BG) } & 01/01/1999 & RTA \\
\hline Slovenia & EFTA & 01/06/1995 & FTA & Bulgaria & Turkey & 01/01/1999 & FTA \\
\hline Poland & WTO & 01/07/1995 & MTS & Estonia & Hungary & $01 / 01 / 1999$ & FTA \\
\hline Slovenia & WTO & $30 / 07 / 1995$ & MTS & Poland & Faroe Islands & 01/06/1999 & FTA \\
\hline Bulgaria & CZ SK & 01/01/1996 & FTA & Poland & Estonia & $01 / 11 / 1999$ & FTA \\
\hline Romania & CZ SK & $01 / 01 / 1996$ & FTA & Estonia & WTO & $13 / 11 / 1999$ & MTS \\
\hline CEFTA $(C$ & $\mathrm{Z}, \mathrm{HU}, \mathrm{PL}, \mathrm{SK}, \mathrm{SI})$ & $01 / 01 / 1996$ & RTA & Bulgaria & Macedonia. FYR & $01 / 01 / 2000$ & FTA \\
\hline Estonia & Ukraine & $14 / 03 / 1996$ & FTA & Hungary & Latvia & $01 / 01 / 2000$ & FTA \\
\hline Estonia & EFTA & 01/06/1996 & FTA & Hungary & Lithuania & $01 / 03 / 2000$ & FTA \\
\hline Estonia & CZ SK & $01 / 07 / 1996$ & FTA & Poland & Turkey & $01 / 05 / 2000$ & FTA \\
\hline CZ SK & Latvia & $01 / 07 / 1996$ & FTA & Slovenia & Turkey & $01 / 06 / 2000$ & FTA \\
\hline Slovenia & Latvia & 01/08/1996 & FTA & Hungary & Croatia & $01 / 01 / 2002$ & FTA \\
\hline Slovenia & Macedonia, FYR & 01/09/1996 & FTA & Poland & Croatia & $01 / 01 / 2002$ & FTA \\
\hline Bulgaria & WTO & 01/12/1996 & MTS & CZ SK & Croatia & $01 / 01 / 2002$ & FTA \\
\hline Bulgaria & Slovenia & $01 / 01 / 1997$ & FTA & Bulgaria & Croatia & $01 / 01 / 2002$ & FTA \\
\hline CZ SK & Israel & 01/01/1997 & FTA & Slovenia & Bosnia \& Herzegovina & $01 / 01 / 2002$ & FTA \\
\hline Estonia & Slovenia & 01/01/1997 & FTA & Bulgaria & Israel & $01 / 01 / 2002$ & FTA \\
\hline Poland & Lithuania & 01/01/1997 & FTA & Bulgaria & Estonia & $01 / 01 / 2002$ & FTA \\
\hline Slovenia & $\mathrm{EC}$ & $01 / 01 / 1997$ & FTA & Bulgaria & Lithuania & $01 / 03 / 2002$ & FTA \\
\hline
\end{tabular}

Source: WTO. 
Figure 2: Average Applied Tariffs, NACE 15-36
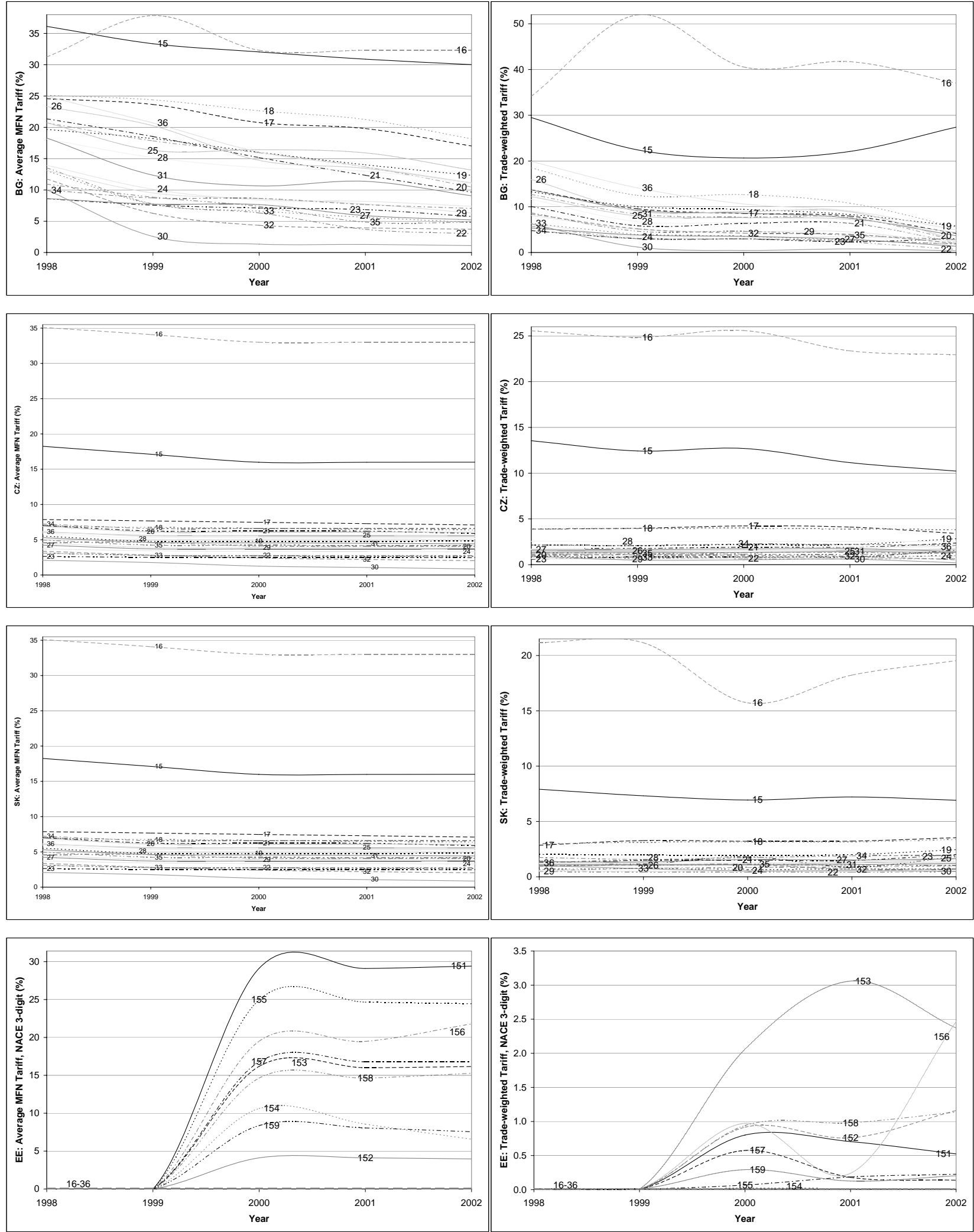

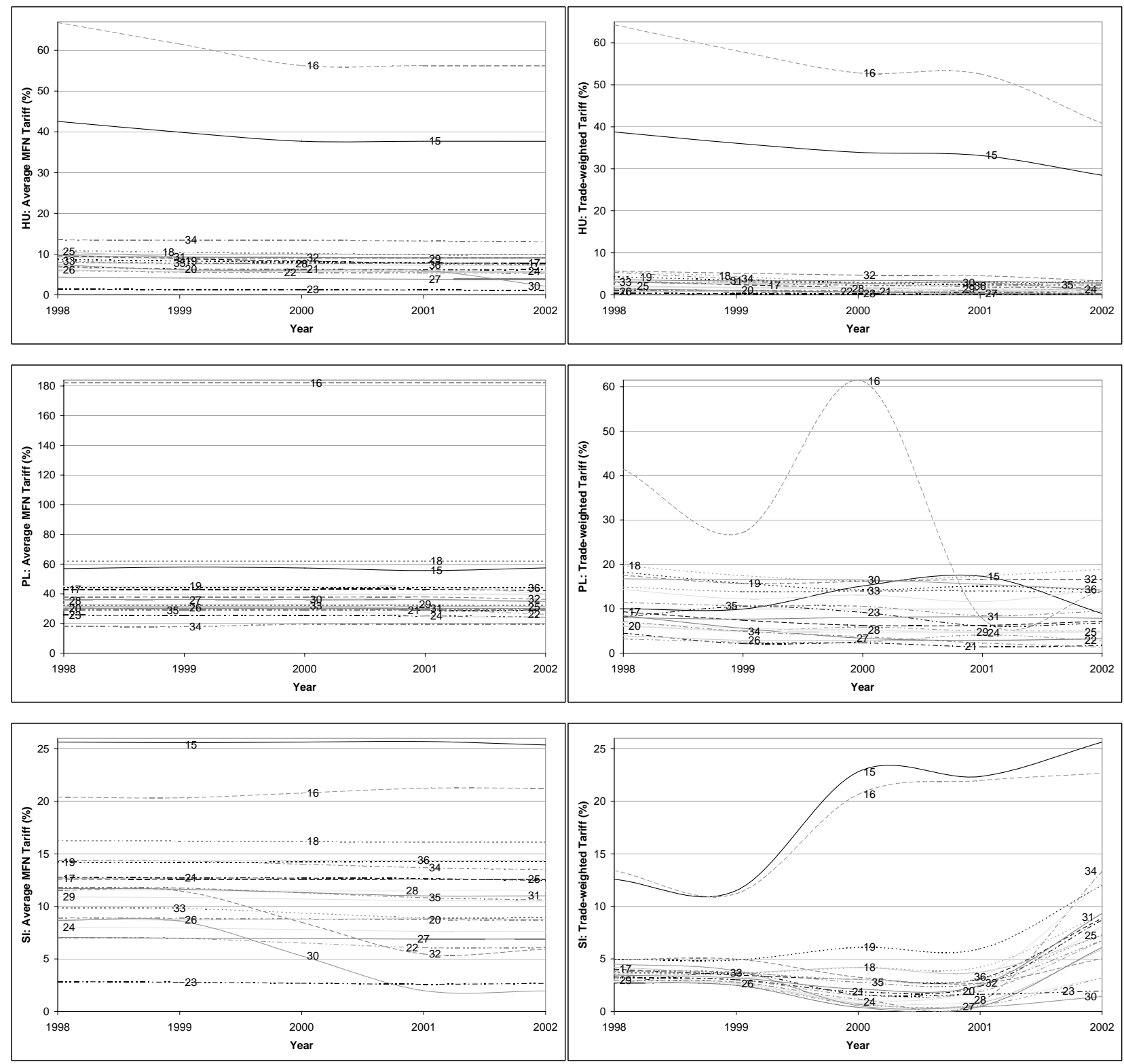

Source: WITS Database 


\section{Appendix B}

\section{Antitrust Legislation - Chronology}

\section{Bulgaria}

1998 New Law on the Protection of Competition (12 May 1998). The Commission for the Protection of Competition (CPC) is given the power to impose sanctions in case of infringement of the law, as well as to order immediate termination of the violation and restoration of the initial situation. Scope of application extended over joint ventures, undertakings with special or exclusive rights and public authorities. Protection of consumer interests is no longer part of the CPC's functions. Detailed methodology for investigation and definition of market position in the relevant market. The Ministry of Finance is empowered with ex post state aid monitoring (annual report and inventory), while the Commission for the Protection of Competition is in charge of ex ante state aid control (authorizing or prohibiting aid projects after compulsory notification).

2001 Block exemption for certain types of vertical agreements. Methodology for the calculation of penalties and fines. Procedural improvements to enhance administrative capacity. A notification format, inventory and annual report on state aid.

2002 Law on State Aid adopted. Sets out the procedural framework for state aid control along with substantive implementing rules.

\section{Czech Republic}

2000 Block exemption for certain types of franchise agreements. The Office for the Protection of Competition is empowered to monitor state aid. Increased transparency, both at the decision-making stage and with respect to information, interpretation and methodology.

2001 New Act on the Protection of Competition (1 July 2001). Scope of application extended over joint ventures, associations and special-purpose undertakings. More precise definition of material competence and extended powers of investigation. Relevant market definition explicitly stipulates substitutability and territory conditions. Dominance is established on the principle of market power, as an aggregate of more criteria than the mere market share. Concept of collective dominance introduced. New methodology and thresholds for agreements falling under the de minimis principle, with explicit distinction between horizontal and vertical agreements. Hardcore restrictions cannot qualify as agreements of minor importance. Refined definition and assessment methodology for concentrations, with thresholds based on turnover. Ex ante notification of intended concentrations required, with possible exemptions from this rule. Leniency program and possibility for negative clearance introduced. Eight block exemption decrees. Modified criteria for granting individual exemption-based exclusively on competition considerations. Methodology for state aid assessment. Maximum timelines for issuing a decision and an extended 3-year term for imposing a fine.

2002 More detailed conditions for the application of a leniency regime. 


\section{Estonia}

1998 New Competition Act (1 October 1998). Ex ante notification of intended concentrations required (monitoring without authority to block). Procedures for notification of concentrations and for the granting of special and exclusive rights. Possibility for block exemptions introduced. Principles and procedure for state aid allocation.

1999 Five block exemption regulations.

2000 Two block exemption regulations. Conditions for the granting of state aid.

2001 New Competition Act (1 October 2001). Matters pertaining to unfair competition no longer within the Competition Board's competence. Refined definition of concentration and increased notification thresholds, no longer based on a market share criterion. Introduced the authority to prohibit a concentration. Seven block exemption regulations. Procedural rules for the granting of special or exclusive rights through public competition. Secondary legislation on state aid introduced.

2002 Competition offenses criminalized. The Competition Board is granted pre-trial investigation powers. Three block exemption regulations. Guidelines for calculation of turnover in concentration assessment.

\section{Hungary}

1997 New Competition Act (1 January 1997). Scope of application extended over natural and legal persons and companies without legal personality, including in case of activities carried out abroad. Provisions relating to consumer fraud and other unfair market practices. Explicit prohibition of all anticompetitive agreements, including vertical ones. Costs and risks of market entry and exit, financial strength of the undertakings, the structure of the relevant market and market shares are among the factors to be taken into account in dominance assessment. Ex ante notification of concentrations required, with turnoverbased thresholds. Five block exemption regulations.

1999 Three block exemption regulations.

2001 Provision that hard-core restrictions among competitors (price-fixing, market allocating agreements) cannot qualify as agreements of minor importance. Individual exemptions for anticompetitive agreements no longer granted for an unlimited period. The definition of 'part of an undertaking' has been added. Simplified definition of 'dominant position'. Adjusted procedural deadlines and levels of disciplinary fines. Possibility for ex ante inquiry into sectors of the economy introduced. Supply-side substitutability explicitly mentioned in the definition of the relevant market. Possibility for conditional exemptions and concentration authorizations. Authority to search private homes and cars with prior court authorization. The basis of a leniency policy is established.

2002 Three block exemption regulations amended in line with EU legislation. Scope of application of the Act on Public Procurement extended. New implementing rules for the Hungary/EC Europe Agreement.

\section{Poland}

1997 Competence extended to include consumer protection matters. 
1999 Higher notification thresholds for concentrations and new methodology for calculation of turnover. A five-year limit for institution of proceedings in case of failure to notify a concentration.

2000 Procedural rules for investigation of monopolistic practices. Detailed requirements for notification of intended concentrations.

2001 New Act on Competition and Consumer Protection (April 2001). Possibility to grant individual and block exemptions, as well as statutory exclusions for agreements of minor importance, but not for hardcore restrictions of competition. Amended regulations enable ex ante use of rule-of-reason analysis. Higher notification thresholds for concentrations and a new methodology for turnover calculation. Procedure for conducting investigations. Regulation on conducting inspections in the course of antitrust proceedings. Framework state aid law enacted.

2002 Detailed procedure for notification of intended concentrations. Four block exemption regulations, taking account of new EU policies on vertical and horizontal restraints. Refined territorial and material jurisdiction. Law on the conditions of admissibility and supervision of state aid for entrepreneurs - refined statutory definitions of state aid, strengthened responsibility of the organs that grant the aid, introduced institutions for aid schemes. Regulations on regional, horizontal and sectoral aid, as well as on procedures.

\section{Slovenia}

1999 New Competition Act (30 June 1999). Introduces investigative powers, procedural rules and penalty provisions. Guidelines on the treatment of joint ventures, market definition and dominance assessment. Concept of joint dominance introduced. Possibility for negative clearance. Exemption of agreements of minor importance, provided that they do not amount to hardcore restrictions of competition. Appeals treated as administrative rather than civil procedures. Individual exemption granted for specified duration and conditions. Explicit prohibition of horizontal and vertical restrictive agreements. Scope of application extended to associations of undertakings and to concerted practices. Market share is an important, but not exclusive criterion for determining dominance. Competencies in anti-dumping procedures. Commission for State Aid Control established and rules of procedure adopted, but legal framework still lacking.

2000 Procedural rules for notification of concentrations. Decree on block exemptions and methodology for defining the relevant market. Framework Act on State Aid Control adopted.

2001 Implementing rules for the application of competition provisions in the Slovenia/EC Europe Agreement.

2002 Decree on block exemptions. Implementing legislation on the allocation of state aids for the rehabilitation of companies in difficulty during restructuring and on economic zones.

\section{Slovak Republic}

1997 Enactment of implementing rules on application of competition provisions stipulated by the Europe Agreement. Competencies in anti-dumping investigations. 
2000 Comprehensive state aid law enacted. The agricultural sector's exemption from antitrust rules is repealed. De minimis rules, negative clearance and possibility for individual exemptions introduced.

2001 New Competition Act (May 2001). Introduces an adjusted concept of entrepreneur, clearer definitions of third party rights and an extended demonstrative list of dominance abuse instances. Market share no longer a criterion for dominance. Control of concentrations extended over joint ventures. Higher turnover and market share thresholds for concentration notification and a methodology for turnover calculation. Concentrations are suspended until a decision has been issued, unless an exemption is granted. Increased market share thresholds in the de minimis regime. Extended timeframes for issuing decisions. Leniency program introduced, along with amended appeal procedures and terms for fine calculation.

2002 Seven block exemption regulations. Simplified procedure for assessment of concentrations with negligible impact. Competencies encompass assessment, evaluation, approval, monitoring and record keeping of state aid. New rules for de minimis aid, aid for employment and training, regional development and SMEs, as well as sensitive sectors. Act on Investment Incentives. Amended fiscal aid schemes. 